\title{
Situational Analysis of Flood and Drought in Rwanda
}

\author{
Samuel Asumadu-Sarkodie ${ }^{*}$, Patrick Rufangura ${ }^{2}$, Herath MPC Jayaweera ${ }^{3}$, Phebe Asantewaa Owusu ${ }^{4}$ \\ Sustainable Environment and Energy Systems \\ ${ }^{1-4}$ Middle East Technical University, Northern Cyprus Campus Kalkanli Guzelyurt, via Mersin 10 TRNC 99738 Turkey. \\ samuel.sarkodie@metu.edu.tr ${ }^{*}$, patrick.rufangura@metu.edu.tr ${ }^{2}$, pradeep.jayaweera@metu.edu.tr ${ }^{3}$, phebe.asantewaa@yahoo.com ${ }^{4}$
}

\begin{abstract}
In this paper, a situational analysis of flood and drought in Rwanda were assessed using AQUEDUCT Global Flood Analyzer based on the population, Gross Domestic Product (GDP) and urban damage for current and future projections (2030). In order to estimate future changes, three scenarios from: Representative Concentration Pathways (RCP) and Shared Socio-economic Pathways (SSP) from the Intergovernmental Panel on Climate Change $5^{\text {th }}$ Assessment Report which represents climate change and socioeconomic change scenarios respectively were employed. Data from 1981-2010 were used to determine the average monthly precipitation for current years and IPCC scenario A2 was employed to generate datasets that predict the average monthly precipitation from 2011-2100 using Meteonorm 7 software. A 10-year flood protection level was employed to ascertain the rate of urban damage, its effects on Gross Domestic Product (GDP) and the Population at risk. The study revealed that, Rwanda has more than $20 \%$ probability of inland flooding in any given year; a 10-year flood has a 10\% probability of occurring in any given year and could cause roughly $\$ 6.1$ million urban damage; $\$ 865.6$ million affected GDP and 837.2 thousand affected population, if there is no flood protection. Flood and drought events cannot be totally eradicated but with mitigation approach and preparedness before its occurrence: social and economic losses can be minimized.
\end{abstract}

Index Terms-AQUEDUCT Global Flood Analyzer, drought, flood, flood protection, IPCC scenarios, Rwanda

\section{INTRODUCTION}

$\mathrm{F}$ lood and drought are the most common forms of natural disaster that disrupt human activities, cause loss of human lives and destroy properties. Floods are caused by extreme excesses of precipitation or unexpected release of an excess amount of water from storage, such as dams or snow pack [1]. Floods tend to be more confined to a small area than droughts and has a shorter lifespan than droughts. Droughts on the otherhand are due to the absence of rain, and thus grow and retreat in severity at rates measured by normal precipitation in an area. In some regions, droughts can persist for many years or decades such as drought in south-west of United States and the Sahel in Africa and in Namibia [1]. Drought has four categories: meteorological, agricultural, hydrological and social-economic drought [2]

According to the United Nations Regional Coordinator in Dakar (October: 2007), the flood that occurred in July, 2007 in West Africa was the most awful kind of flood in thirty years. This is because, more than 210 deaths were recorded and more than 785,000 people were affected. In the press conference after the flood crisis evaluating the impact of the flood in 2007, it was revealed that the rains affected almost a half of African countries bringing the total death to more than 350 with hundreds of thousands of inhabitants displaced. For example; Nigeria (68 deaths and 50,000 affected), Ghana (56 deaths and 332,000 affected), Burkina Faso (46 deaths and 92,979 affected) and Togo (with 23 deaths and 120,000 affected, of which 11,483 have been displaced) were the most affected countries according to the press conference [3].

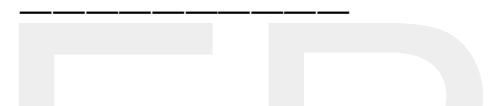

In general, flood losses have greatly increased over the years due to land-use amendment, urbanization of flood-prone areas, subcustomary construction, and high population density. Cities are more prone to floods than rural areas because of high population densities and concentration of economic activities. The east and south eastern regions in Rwanda experienced devastating period of drought and heat waves which resulted in extreme poverty and food insecurity because the food basket of the country is located in these regions [4].

Historically, Rwanda has experienced all these extreme events and each event was accompanied by both social and economic damages. Recently, the rate of occurrence of either floods, drought or both has being on the increase for each water year. Against this backdrop, the study deems necessary to ascertain the causes of flood and drought in Rwanda and how best it can be managed to serve as a bequest for future generations.

\subsection{Demographics}

Rwanda, known as the "Country of a Thousand Hills" is one of the smallest countries in Africa with a total area estimated to be $26,338 \mathrm{~km}^{2}$ and is situated in the tropical belt (latitude: $1^{\circ} 51^{\prime} \mathrm{S}$ $2^{\circ} 51^{\prime} \mathrm{S}$ and Longitude $\left.28^{\circ} 52^{\prime} \mathrm{E}-30^{\circ} 55^{\prime} \mathrm{E}\right)$, sits across two basic climatic regions: East Africa and Central Africa, each with a contribution to the climate of the Country [5]. The country's relief is hilly and mountainous (country of thousands hills). Average altitude of hills in Rwanda is about $1000 \mathrm{~m}$ above sea level. The central plateau is at elevation of $1500 \mathrm{~m}$ to $2000 \mathrm{~m}$ high, whiles the 
higher elevation is found in the northwest part bordered with Democratic Republic of Congo, and with the volcanic region at an altitude of $4507 \mathrm{~m}$. This relief characteristics play a big role in the weather patterns and disaster occurrence in different regions of country. The Northwest region have lots of rainfall and experiences more landslides and floods in the plains and swamps whiles the Central plateau and Eastern parts of the country are the most vulnerable regions for droughts due to low rainfall intensities [6].

Rwanda is one of the dense populated countries in Africa with a total population of about 11 million people [7] and an agricultural based economy which contributes to one-third of the total GDP. However, the country is in land crisis due to population growth and over-dependence on traditional agricultural system. According to Rwanda Environmental Authority, land cultivation has increased from 782,500 ha (1984) to 899,133 ha (2002). As a result of this, overexploitation and degradation of these lands have led to erosion; and disasters such as: landslides, floods and droughts in different region of the country [8].

Rwanda is in the tropical temperate zone near to the equatorial belt. The average temperature relies on the elevation of it mountains. The lowest Temperature varies from $15^{\circ} \mathrm{C}$ to $17^{\circ} \mathrm{C}$ observed in the North and Northwest regions. The maximum temperature varies from $19^{\circ} \mathrm{C}$ to $21^{\circ} \mathrm{C}$ observed in the Central plateau, Southwest and Eastern savannah regions, where maximum temperature goes beyond $30^{\circ} \mathrm{C}$ during summer [4]. Precipitation is controlled by Inter-tropical convergence zone (ITCZ) which occurs twice per year and determines the two rainy seasons in the country. ITCZ is accompanied by low pressure, high humidity air and convergence wind. From mid-September to December, higher wind blows from the Northeast, humidified masses from Indian Ocean and Victoria Lake followed by a short rainy season. On the contrary, dry and cold air from the Arabians and Dorsal blows from Mid-December to the end-of-February followed by a short dry season. Huge rainfalls are observed during the long rainy season (March to June) whereas, the long dry season (summer) starts in June to Mid-September [5].

Rwanda heads two most distinctive rivers in Africa namely; Nile and Congo River which are located in the Southwestern region. Nile crest covers about $67 \%$ of all the country's territory and contributes $90 \%$ of the country's water consumption. In constrast, Congo crest cover the remaining percentage and divert towards the Western province. Due to its geographic location, topography and moderate climate, Rwanda has more water-reserve: both surface and underground water. Underground water recharge capacity is about 5 billion cubic meters per year ( 177 billion $\mathrm{ctt} / \mathrm{yr}$ ) [9]. Rwanda is endowed with: 101 lakes which occupies a surface area of 149,487 ha, 861 rivers and 860 marshlands which occupies a surface area of 278,536 ha [5]. In Figure 1, an administrative map of Rwanda is given.

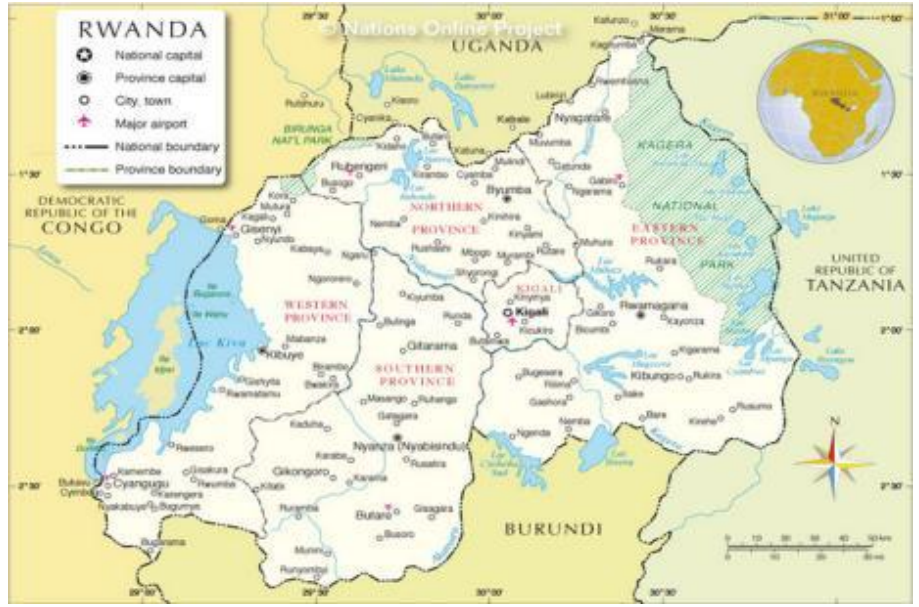

Fig. 1. Administrative Map of Rwanda

\subsection{History of flood and drought in Rwanda}

Flood and drought constitutes the majority of natural disasters that occur in Rwanda. According to report on natural disasters and hazards in Rwanda, flood is the most occurred extreme event in Rwanda but third on the list after epidemics with regards to lost of lives, however, drought is the second on the list with regards to lost of lives but third in terms of occurrence of natural disasters in Rwanda (Table 1). About 237 people out of 4.16 million people have lost their lives from 1900 to 2015 as a result of drought events; however, about 183 people out of almost 82,000 people lost their lives from 1900 to 2015 due to flood events [10]. According to EM-DAT: 2015, economical losses caused by flood in Rwanda is roughly US\$9,000 (Table 1) [10].

Similarly to other East African countries, Rwanda experiences flood and long period of drought events. Flood events mainly occur during rainy seasons from September-November and AprilMay [13]. Historically, North and Western provinces of Rwanda are the most vulnerable to: floods, land slides and erosion. Due to the higher elevation of the North and Western provinces, lots of residential buildings occupy the feet of the mountains and floodplains which blocks water channels leading to flooding [7]. Deforestation of the Gishwati natural forest which once played a critical role in preventing the region from erosion is another factor leading to increasing flood frequency events in this region [7]. The flood that occurred in September-December, 2001 led to a death toll of 108 in this region [3]. In May 2010, another huge flood killed 13 people, destroyed 237 hectares of crops, and displaced 140 houses [6].

Six drought events have occurred in Rwanda as a result of long periods of dry season or delayed in rainy season: a long dry period from 1998-2000 and an annual drought from 2002-2005 [11]; resulting in 237 deaths and affecting almost 4.2 million people (Table 1). During this period, the country's economy was affected, especially in the agricultural sector due to food 
insecurity: this affected crop yield and reduced livestock production especially in the Eastern and Southeastern parts of Rwanda [4]. Due to the prolonged drought in 2005, water-levels in Burela and Ruhondo lakes declined resulting in a deficit in hydropower production leading to power crisis (low shedding and power outages) [12]. In Table 1, the natural disasters in Rwanda from 1900 to 2015 are given.

Table 1. Natural Disasters in Rwanda from 1900 to 2015 [10]

\begin{tabular}{lcccc}
\hline Disaster & $\begin{array}{c}\text { № of } \\
\text { Events }\end{array}$ & Killed & $\begin{array}{c}\text { Total } \\
\text { Affected }\end{array}$ & $\begin{array}{c}\text { Damage } \\
\text { (US\$) }\end{array}$ \\
\hline Drought & 6 & 237 & $4,156,545$ & - \\
Flood & 12 & 183 & 82,308 & 9,000 \\
Epidemic & 11 & 317 & 7,259 & - \\
Landslide & 3 & 45 & 7937 & - \\
Earthquake & 2 & 81 & 2,286 & - \\
\hline
\end{tabular}

\subsection{Flood and Drought Management Strategies}

Currently, the Government of Rwanda has put in place more flood protection measures: both structural and non-structural. For Structural measures, the Government of Rwanda has constructed a retention pond at Muhazi Lake to prevent flood from the lake, a number of new water channels have been constructed and old channels renewed in Kigali city [14]. For non-structural measures, Kigali city council in collaboration with other Government institutions and communities have educated residents to implement rainwater harvesting from roof-tops. Nonetheless, an optimal solution to flood depends on knowledge that is complete, precise and accurate. In light of the uncertainties about the future, flood management plans should adopt strategies that are flexible, resilient and adaptable to changing conditions. Such strategies would be multi-faceted with a mix of options (see Table 2) [15]. To mitigate drought in Bugesera, several trees have been planted for restoration of the forest: 2.9 million trees have been planted from 2005 to 2012 through the reforestation programme [16]. In Table 2, the strategies and options for flood management in Rwanda are given.
Table 2. Strategies and Options for Flood Management [15]

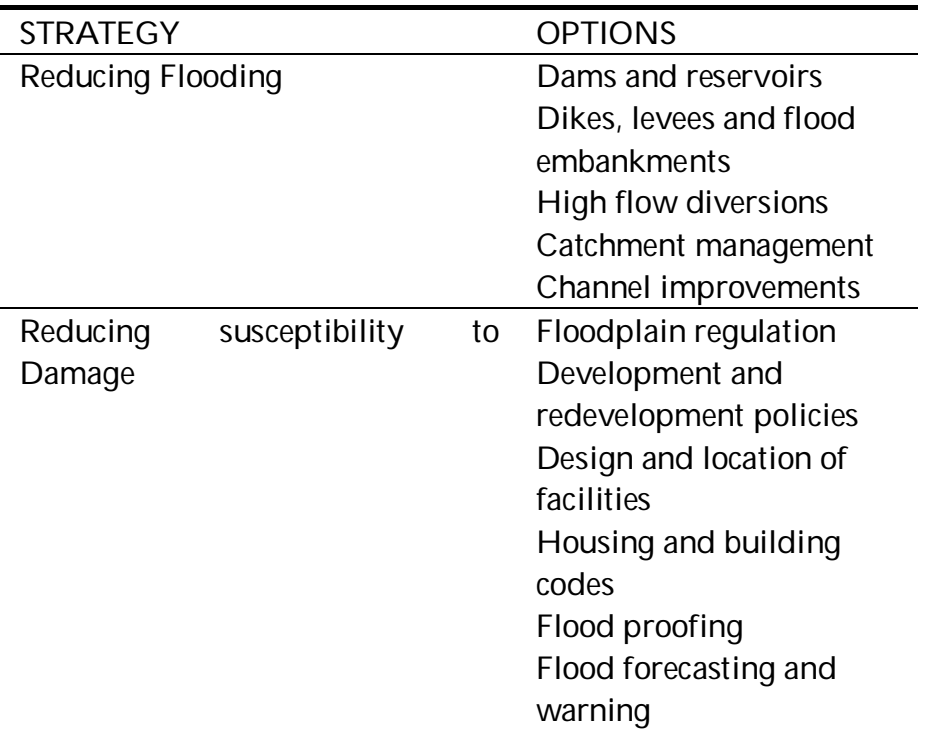

Mitigating the impacts of flooding Information and

education

Disaster preparedness

Post-flood recovery

Flood insurance

Preserving the Natural Resources Floodplain zoning and of Flood Plains regulation

\section{MATERIALS AND METHODS}

Meteorogical dataset employed in this study was generated using Meteonorm 7 software. This is the first of its kind where Meteonorm 7 software is employed to generate precipitation data for flood and drought analysis. Data from 1981-2010 were used to determine the average monthly precipitation for current years. In order to establish a strong correlation between average monthly precipitation, droughts and floods, Intergovernmental Panel on Climate Change (IPCC) scenario A2 was used to generate datasets that predict the average monthly precipitation from 2011-2100. The A2 scenario is "based on a high population growth scenario of 15 billion by 2100 that assumes a significant decline in fertility for most regions and stabilization at above replacement levels" [17]. Many studies have employed rainfall amount as a reliable indicator of climate change variability [18] which results in either flooding or drought.

Flood risk in Rwanda was analyzed using AQUEDUCT Global Flood Analyzer [19]. AQUEDUCT Global Flood Analyzer estimates flood risk of a country based on the population, Gross Domestic Product (GDP) or urban damage for both current and the future (2030) years. In order to estimate future changes, three scenarios were used: RCP (Representative Concentration Pathways) 4.5 and SSP (Shared Socio-economic Pathways)2 from IPCC $5^{\text {th }}$ Assessment Report which represent climate change and socioeconomic change scenarios respectively. The future scenarios 
take into account both climate change and socio-economic change. In Scenario $\mathrm{A}, \mathrm{RCP}_{4.5}$ assumes moderate climate change whilst $\mathrm{SPP}_{2}$ assumes continued current socio-economic development trends [20].

RCP (Representative Concentration Pathways) 8.5 and SSP (Shared Socio-economic Pathways) 2 from IPCC $5^{\text {th }}$ Assessment Report which represent climate change and socioeconomic change scenarios respectively. The future scenarios take into account both climate change and socio-economic change. In Scenario B, RCP 8.5 assumes severe climate change whilst $\mathrm{SPP}_{2}$ assumes continued current socio-economic development trends [20].

RCP (Representative Concentration Pathways) 8.5 and SSP (Shared Socio-economic Pathways) 3 from IPCC $5^{\text {th }}$ Assessment Report which represent climate change and socioeconomic change scenarios respectively. The future scenarios take into account both climate change and socio-economic change. In Scenario $\mathrm{C}, \mathrm{RCP} 8.5$ assumes severe climate change whilst $\mathrm{SPP}_{3}$ assumes uncontrolled population growth and fragmented economies [20].

Flood occurrence (FO) measures the number of floods recorded in each catchment between 1985 and 2011. Based on this, the reported flood extent were taken from the Global Flood Observatory and estimated from remote sensing, governmental and media reports of the Rwanda [21, 22]. Its mathematically model is as follows:

$r_{F O, j}=\operatorname{count}(\{E \mid E \cap j \neq \emptyset\})$

Where, $E$ is extent polygons which are spatially joined to catchments $j$ in order to count the total number of floods that may be affected by each catchment over the recorded period of time.

Drought severity (DRO) on the other hand measures the mean severity of drought events from 1901 to 2008 as recorded in a modeled $1^{\circ} \times 1^{\circ}$ gridded data set by Sheffield and Wood [21, 23]. The dataset is generated by a monthly soil moisture hydrograph for each of the grid cell, and the defined drought runs as a continuous period in as soil moisture falls under the $20^{\text {th }}$ percentile of the monthly hydrograph $(q(\Theta)<20 \%)$.

$S=\sum_{t=t_{i}}^{t+D-1} 20 \%-q(\Theta)_{t}$ i.e. $S=I \times D$

Where, $S$ is the severity of a drought that runs at the beginning of time, $\boldsymbol{t}_{\boldsymbol{i}}$, D is the length of drought measured in months, $\boldsymbol{I}$ is the intensity which is equal to the average number of points by which the soil moisture falls below the $20^{\text {th }}$ percentile.

Resampling the gridded mean severity $(S)$ dataset and average across the hydrological catchments in Rwanda. It is calculated by AQUEDUCT Global Flood Analyzer as:

$r_{D R O, j}=\sum_{P \subset j} \operatorname{mean}(S)_{p}$

\section{RESULTS AND DISCUSSION}

Rwanda is facing crisis with its water resources as a result of current population growth and climate change leading to increased period of drought and rainful anomalies. In Figure 2, access to water map of Rwanda is given. Using AQUEDUCT Water Risk Atlas for access to water analysis, Rwanda has an extremely high ( $>20 \%$ probability) risk of populace having less access to safe drinking water supplies, indicating high reputational risks to those using water inequitably. Access to water measures the percentage of population without access to improved drinking water sources [24, 25].

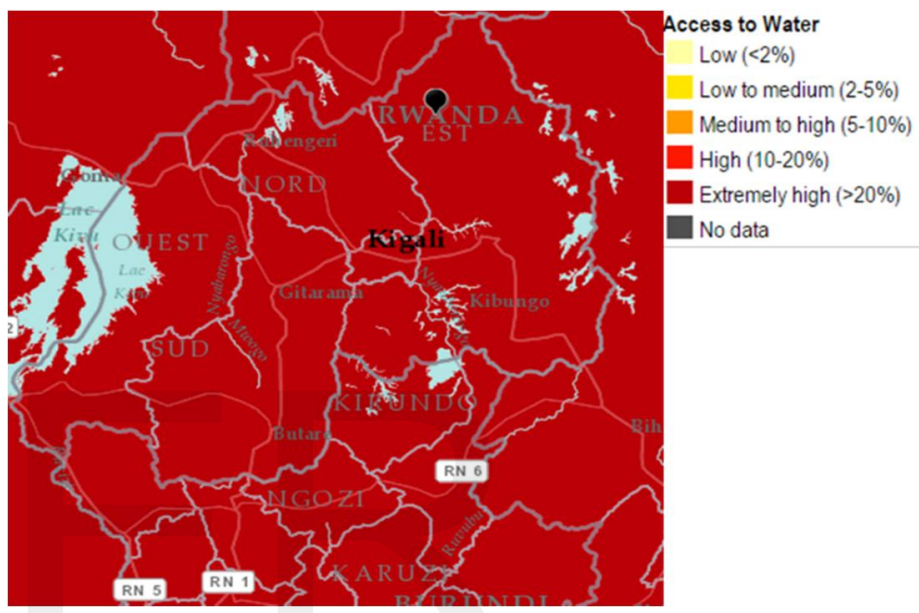

Fig. 2. Access to water map of Rwanda.

Statistics (1971-2010) show that there is an increase in annual mean temperature of $0.35^{\circ} \mathrm{C}$ per decade which is higher than the global annual mean temperature increase of $0.27^{\circ} \mathrm{C}$ observed from 1979 to 2005 [26]. Future projections show that temperatures will increase to $2.7^{\circ} \mathrm{C}$ and $4^{\circ} \mathrm{C}$ in 2050 and 2080 respectively. Rainfall projections on the other hand shows an increase of $20 \%$ by 2050 and $30 \%$ by 2080 . This means that, increasing temperature and rainfall in Rwanda will result in more floods and droughts events in the future [27]. In Figure 3, the predicted annual change in temperature and precipitation in Rwanda are given.

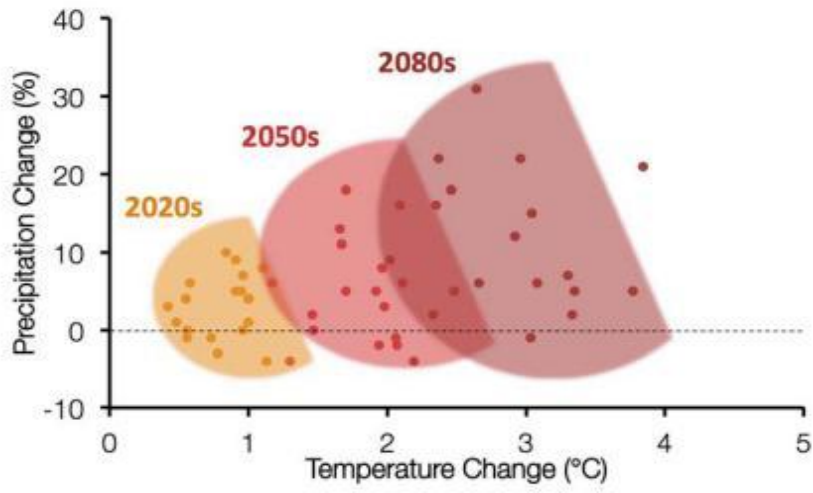


Fig. 3. Predicted change in temp. and precipitation [27]

In Figures 4-5, the average monthly precipitation from year 19811990 and 1991-2010 for Nyabugogo and Bugesera are given. In Figure 4 and 5, it is evident that there are no observable changes in precipitation from year 1981-1990 and 1991-2010.
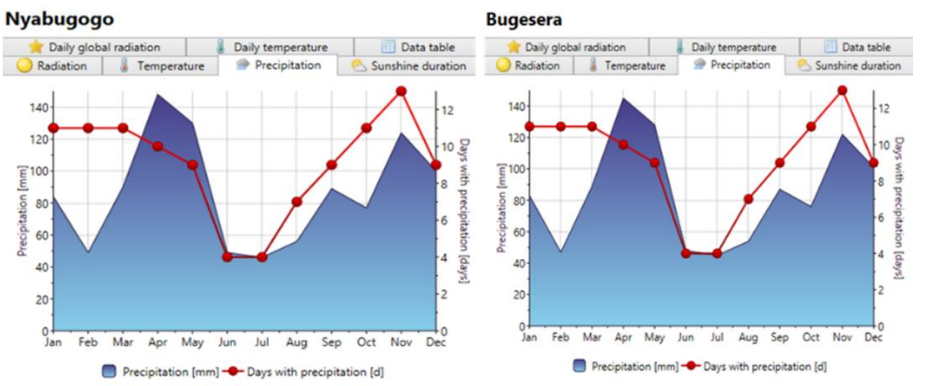

Fig. 4. Average monthly precipitation from 1981-1990.

In Figures 6-14, the predicted average monthly precipitation from 2011-2020; 2021-2030; 2031-2040; 2041-2050; 2051-2060; 2061-2070; 2071-2080; 2081-2090 and 2091-2100 for Nyabugogo and Bugesera are given. In Figures 9-17, it is evident that there is a sharp decline in precipitation in June, July and August but very prominent in July from $45 \mathrm{~mm}$ in 1981-1990 and 1991-2010 to below $20 \mathrm{~mm}$. This downward trend in precipitation is of considerable importance to drought severity in Rwanda. However, there is a constant increase in precipitation in April with increasing years, from $150 \mathrm{~mm}$ in 1981-1990 and 1991-2010 to more than $200 \mathrm{~mm}$ in 2091-2100. Notwithstanding, increasing precipitation in April occurs in less than 10 days. This upward trend in precipitation in April, occurring in less than 10 days in all the years, is critical to flood occurence in Rwanda.

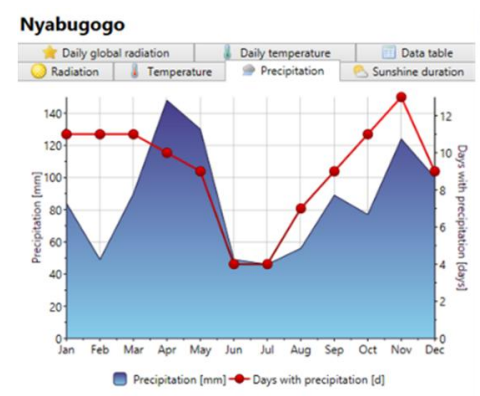

Bugesera
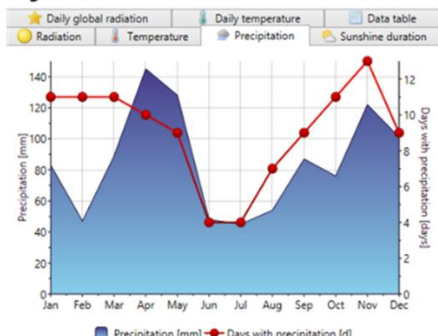

- Precipitation $[m m]-0$ ays with precipitation [ol

Fig. 5. Average monthly precipitation from 1991-2010.

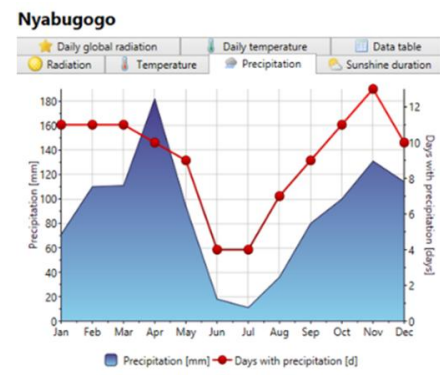

Bugesera

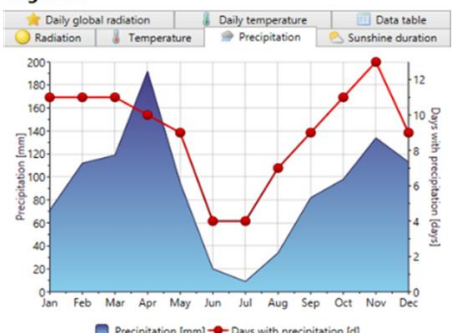

Fig. 6. Predicted average monthly precipitation from 2011-2020.
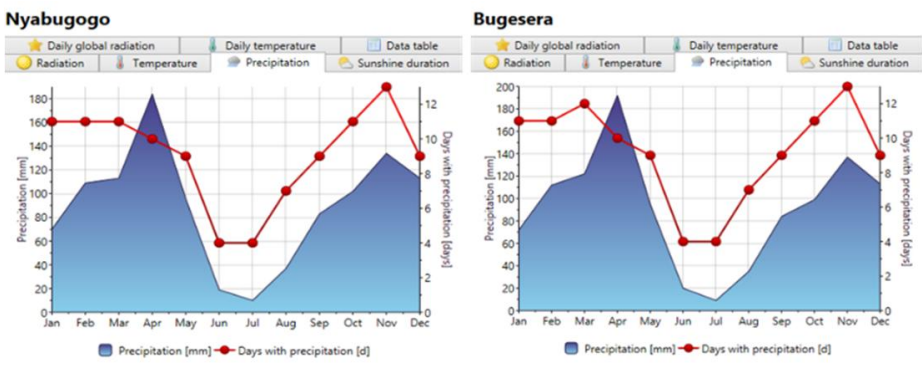

Fig. 7. Predicted average monthly precipitation from 2021-2030.
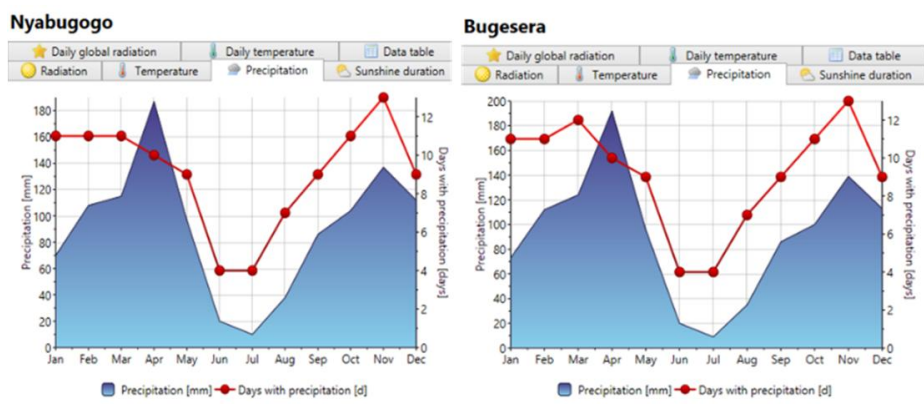

Fig. 8. Predicted average monthly precipitation from 2031-2040.
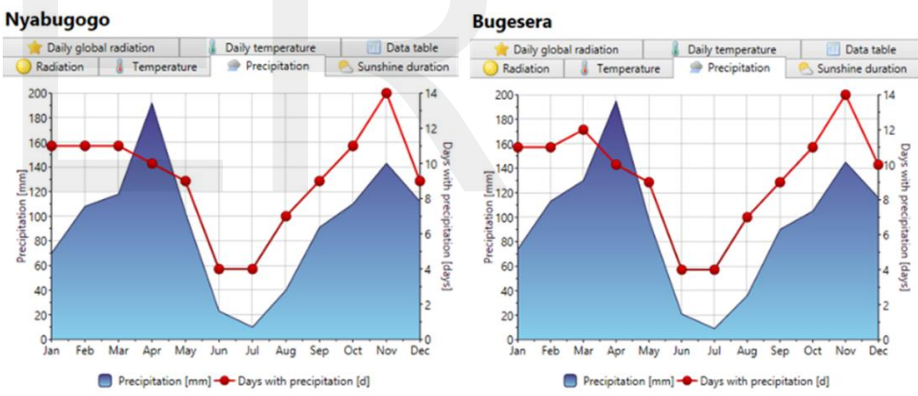

Fig. 9. Predicted average monthly precipitation from 2041-2050.
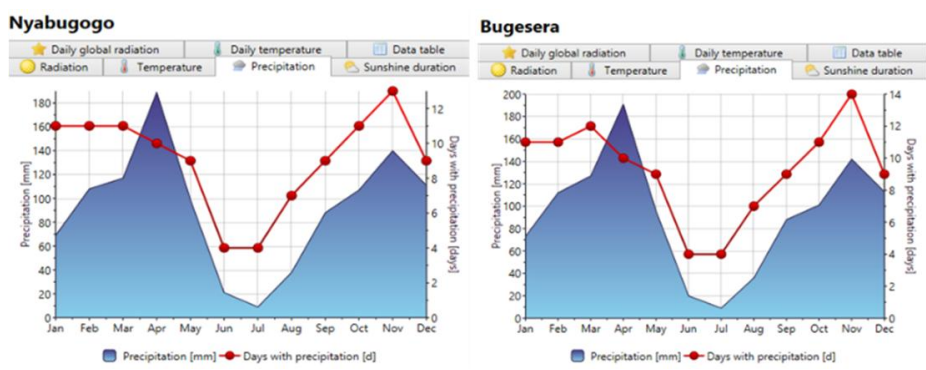

Fig. 10. Predicted average monthly precipitation from 2051-2060. 


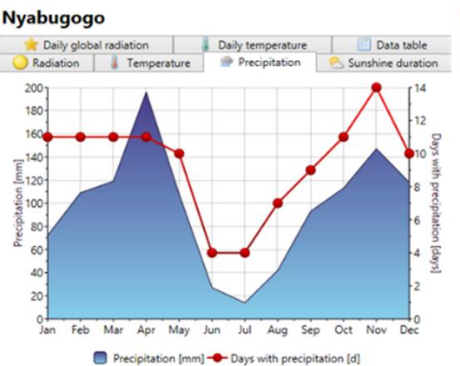

Bugesera

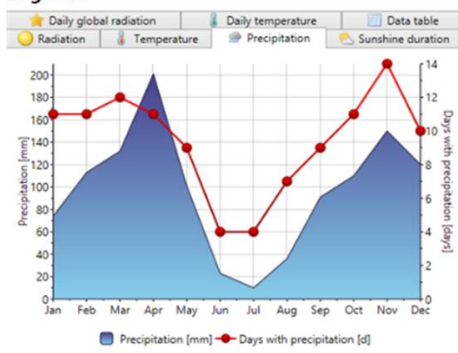

Fig. 11. Predicted average monthly precipitation from 2061-2070.
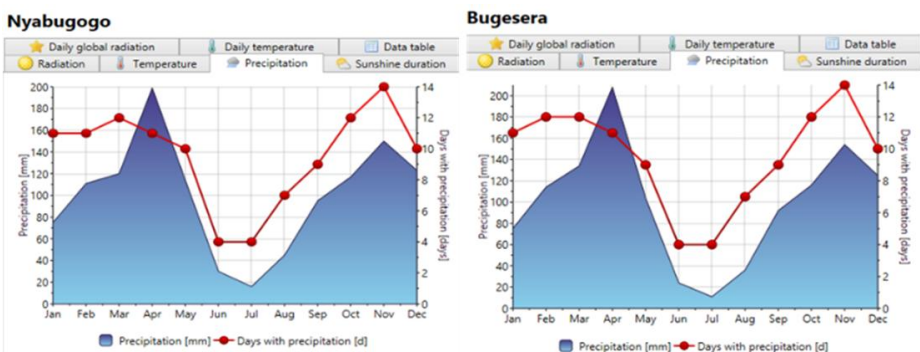

Fig. 12. Predicted average monthly precipitation from 2071-2080.

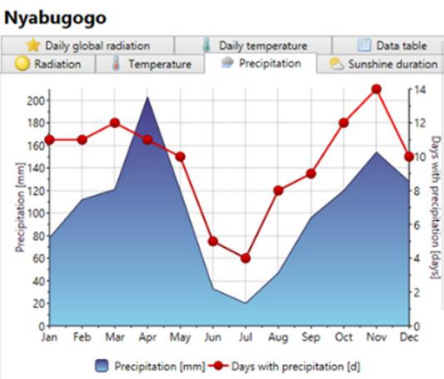

Bugesera

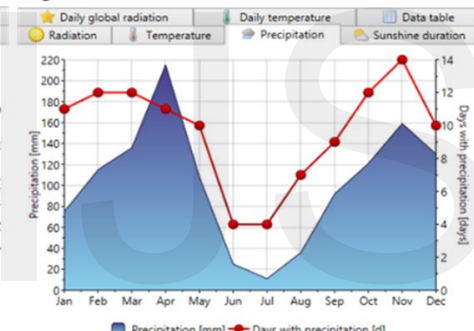

Fig. 13. Predicted average monthly precipitation from 2081-2090.
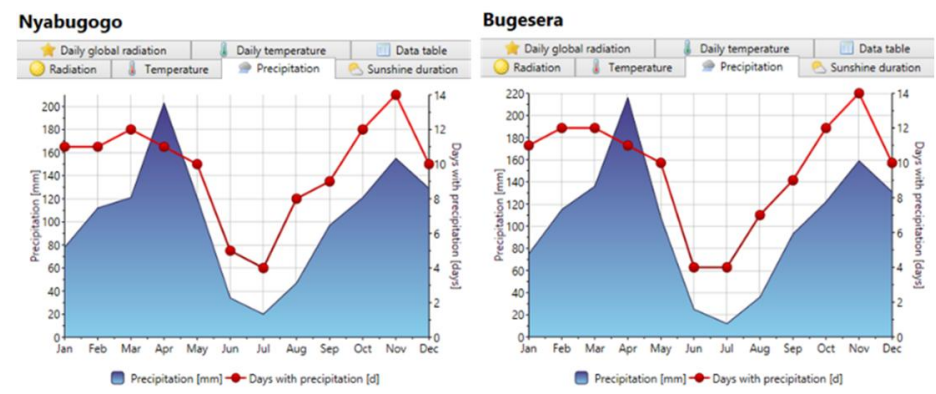

Fig. 14. Predicted average monthly precipitation from 2091-2100.

\subsection{Flood Risk Assessment in Rwanda}

A 10-year flood protection level was used to ascertain the rate of urban damage, how it affects Gross Domestic Product (GDP) and the population at risk. Flood protection level describes how well protected any given area is against flood damage [19]. Using AQUEDUCT Water Risk Atlas for flood occurrence analysis, Rwanda has a high (10-27 \% probability) tendency of flood occurrence. This is a count of the number of flood recorded from 1985-2011 [28]. In Figure 15, the flood risk map of Rwanda is given.

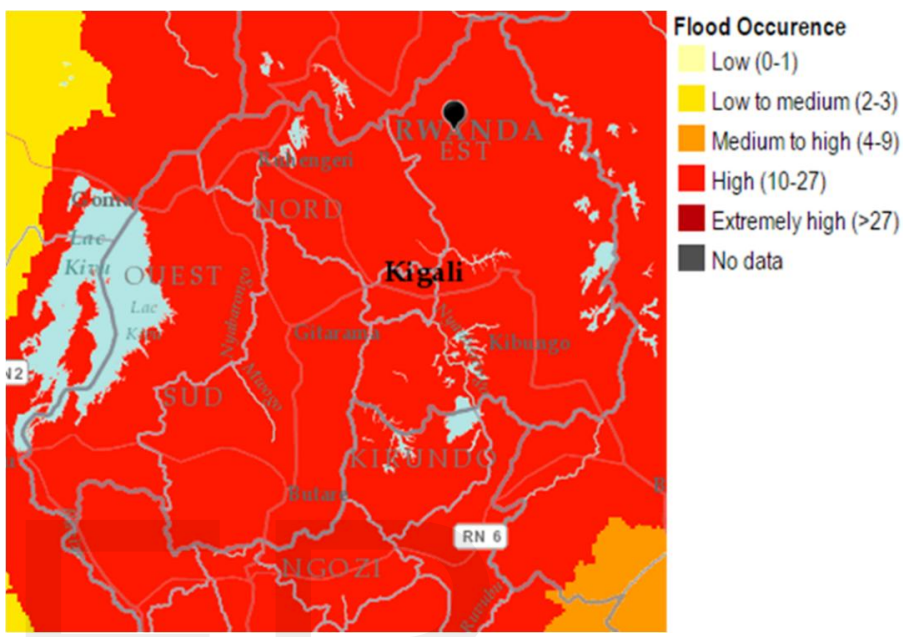

Fig. 15. Flood Risk Map of Rwanda.

Currently, Rwanda has more than $20 \%$ probability of inland flooding in any given year. In Figure 16, the probability of inland flooding in any given year in Rwanda is given.

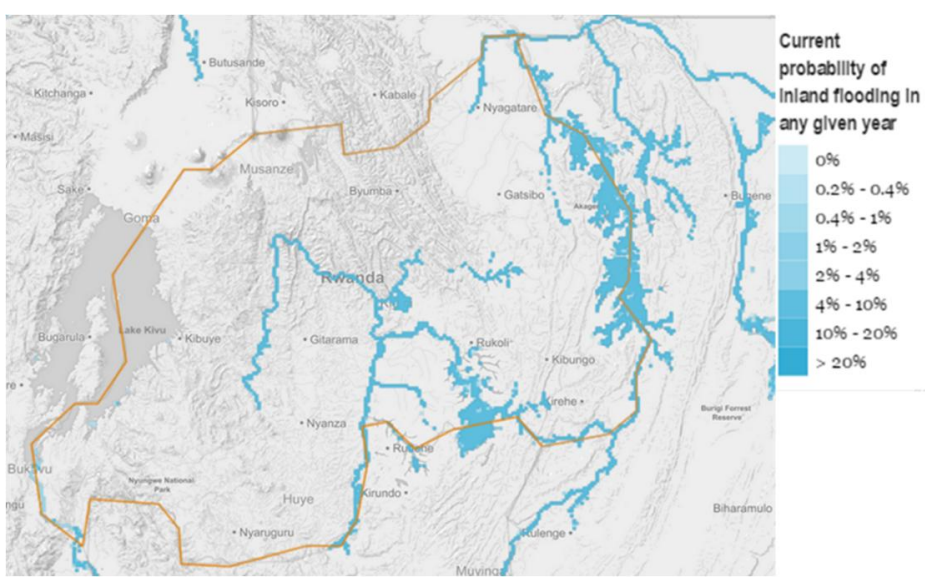

Fig. 16. Probability of inland flooding in any given year in

Rwanda. 


\subsubsection{Urban Damage in Rwanda}

To estimate the urban damage, the annualized direct damage to assets due to inland flooding in urban areas were employed. In Figure 17, the urban damage based on a 10-year flood protection level in Rwanda is given.

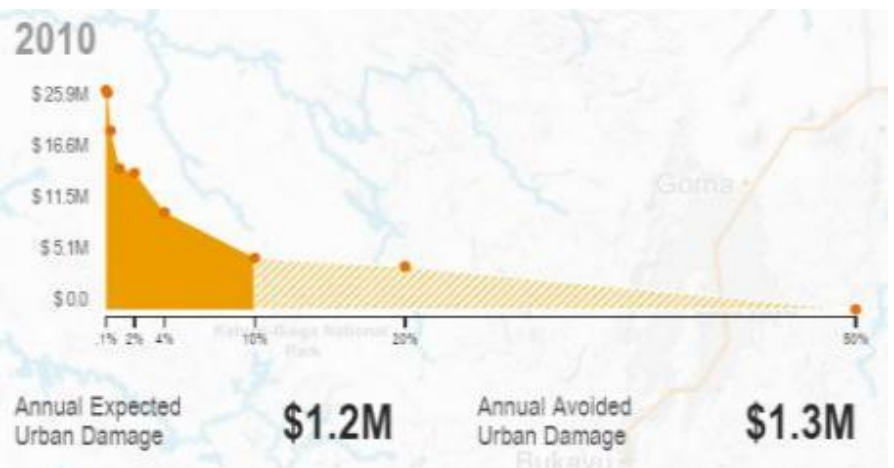

Fig. 17. Urban damage based on 10 year flood protection level.

In Figure 17, a 1000-year flood has a $0.1 \%$ probability of occurring in any given year, and could cause roughly $\$ 25.9$ million urban damage in Rwanda, if there is no flood protection. A 250-year flood has a $0.4 \%$ probability of occurring in any given year, and could cause roughly $\$ 21.1$ million urban damage in Rwanda, if there is no flood protection. A 100 -year flood has a $1 \%$ probability of occurring in any given year, and could cause roughly $\$ 16.6$ million urban damage in Rwanda, if there is no flood protection. A 50 -year flood has a $2 \%$ probability of occurring in any given year, and could cause roughly $\$ 16.1$ million urban damage in Rwanda, if there is no flood protection. A 25-year flood has a $4 \%$ probability of occurring in any given year, and could cause roughly $\$ 11.5$ million urban damage in Rwanda, if there is no flood protection. A 10-year flood has a $10 \%$ probability of occurring in any given year, and could cause roughly $\$ 6.1$ million urban damage in Rwanda, if there is no flood protection. A 5-year flood has a $20 \%$ probability of occurring in any given year, and could cause roughly $\$ 5.1$ million urban damage in Rwanda, if there is no flood protection. A 2-year flood has a $50 \%$ probability of occurring in any given year, and could cause roughly $\$ 0.0$ urban damage in Rwanda, if there is no flood protection. In Figure 18, the urban damage in Rwanda for 2030 based on Scenario A is given.

In Figure 18, the current annual expected damage in Rwanda is $\$ 1.2$ million accounting for its existing country-wide average 10year flood protection. By 2030 assuming there is no additional flood protection introduced, roughly $72.9 \%$ of the expected increase in annual urban damage in Rwanda could be driven by socio-economic change. By 2030 assuming there is no additional flood protection introduced, $27.1 \%$ roughly of the expected increase in annual urban damage in Rwanda could be driven by climate change. By 2030 assuming there is no additional flood protection introduced, annual urban damage could reach $\$ 12.7$ million in Rwanda. In Figure 19, the urban damage in Rwanda for 2030 based on Scenario $B$ is given.

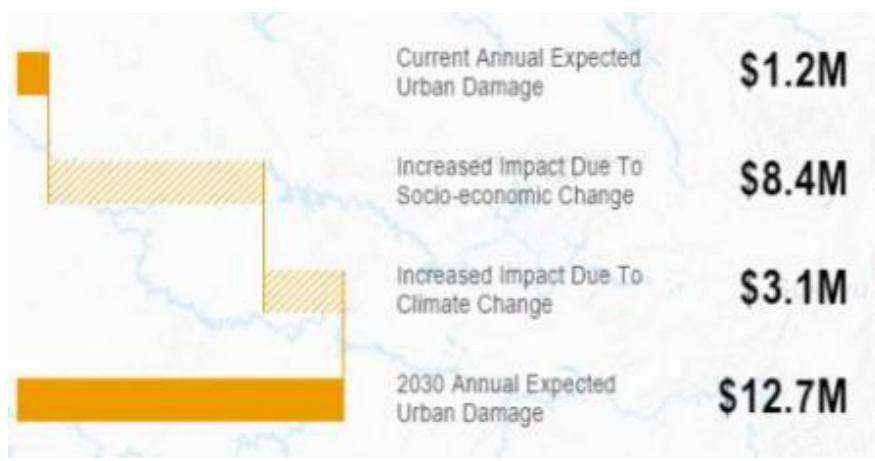

Fig. 18. Urban damage in Rwanda for 2030 based on Scenario A.

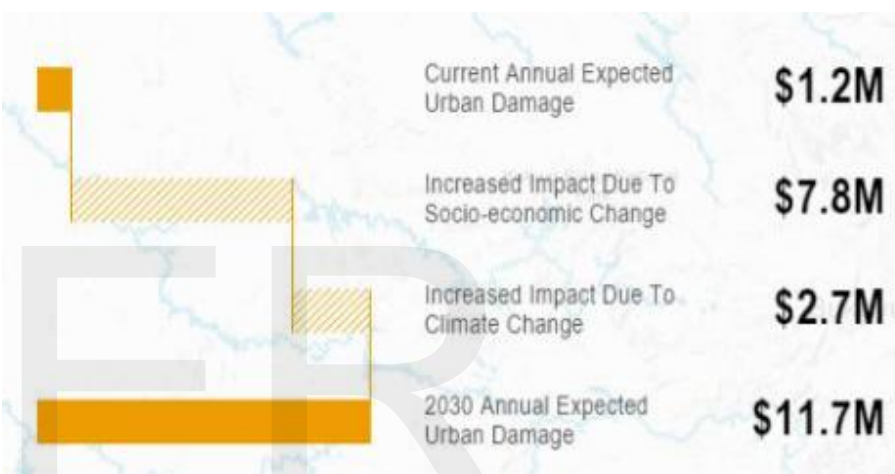

Fig. 19. Urban damage in Rwanda for 2030 based on Scenario B.

In Figure 19, the current annual expected damage in Rwanda is $\$ 1.2$ million accounting for its existing country-wide average 10year flood protection. By 2030 assuming there is no additional flood protection introduced, roughly $74.2 \%$ of the expected increase in annual urban damage in Rwanda could be driven by socio-economic change. By 2030 assuming there is no additional flood protection introduced, $25.8 \%$ roughly of the expected increase in annual urban damage in Rwanda could be driven by climate change. By 2030 assuming there is no additional flood protection introduced, annual urban damage could reach $\$ 11.7$ million in Rwanda. In Figure 20, the urban damage in Rwanda for 2030 based on Scenario $C$ is given.

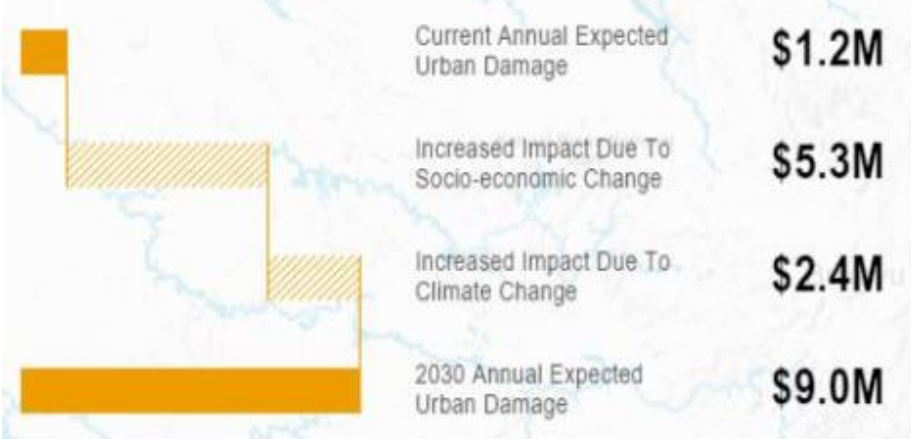


Fig. 20. Urban damage in Rwanda for 2030 based on Scenario C.

In Figure 20, the current annual expected damage in Rwanda is $\$ 1.2$ million accounting for its existing country-wide average 10year flood protection. By 2030 assuming there is no additional flood protection introduced, roughly $68.8 \%$ of the expected increase in annual urban damage in Rwanda could be driven by socio-economic change. By 2030 assuming there is no additional flood protection introduced, $31.2 \%$ roughly of the expected increase in annual urban damage in Rwanda could be driven by climate change. By 2030 assuming there is no additional flood protection introduced, annual urban damage could reach $\$ 9.0$ million in Rwanda.

\subsubsection{Affected Gross Domestic Product (GDP)}

Affected GDP estimates the annualized Gross Domestic Product (GDP) affected by inland flooding in any given area. The Global Flood Analyzer overlays a global inundation map on a global GDP map to reveal the dollar value of assets regularly exposed to inland floods [19]. In Figure 21, the affected GDP based on a ten (10) year flood protection level in Rwanda is given.

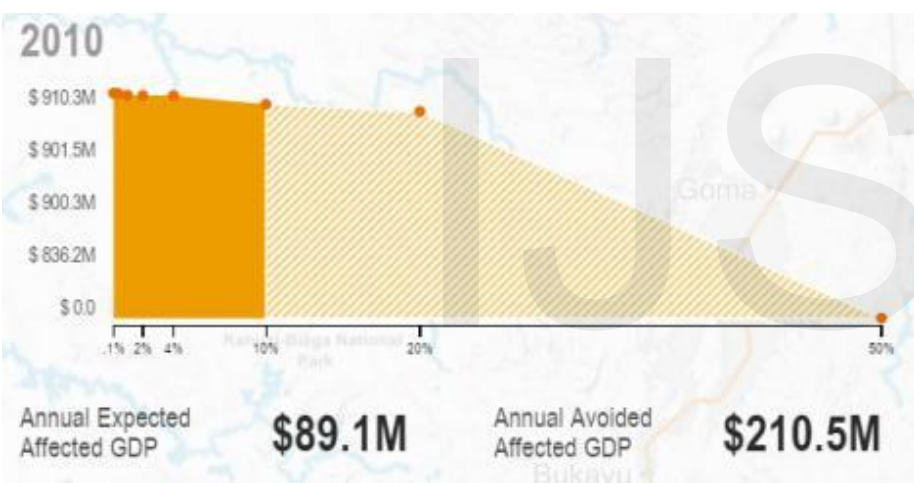

Fig. 21. Affected GDP based on a 10 year flood protection level.

In Figure 21, a 1000-year flood has a $0.1 \%$ probability of occurring in any given year, and could cause roughly $\$ 910.3$ million affected GDP in Rwanda, if there is no flood protection. A 250-year flood has a $0.4 \%$ probability of occurring in any given year, and could cause roughly $\$ 908.3$ million affected GDP, if there is no flood protection. A 100 -year flood has a $1 \%$ probability of occurring in any given year, and could cause roughly $\$ 901.5$ million affected GDP, if there is no flood protection. A 50-year flood has a $2 \%$ probability of occurring in any given year, and could cause roughly $\$ 900.6$ million affected GDP, if there is no flood protection. A 25 -year flood has a $4 \%$ probability of occurring in any given year, and could cause roughly $\$ 900.3$ million affected GDP, if there is no flood protection. A 10-year flood has a $10 \%$ probability of occurring in any given year, and could cause roughly $\$ 865.6$ million affected GDP, if there is no flood protection. A 5-year flood has a $20 \%$ probability of occurring in any given year, and could cause roughly $\$ 836.2$ million affected
GDP, if there is no flood protection. A 2-year flood has a 50\% probability of occurring in any given year, and could cause roughly \$0.0 affected GDP in Rwanda, if there is no flood protection. In Figure 22, the affected GDP in Rwanda for 2030 based on Scenario A is given.

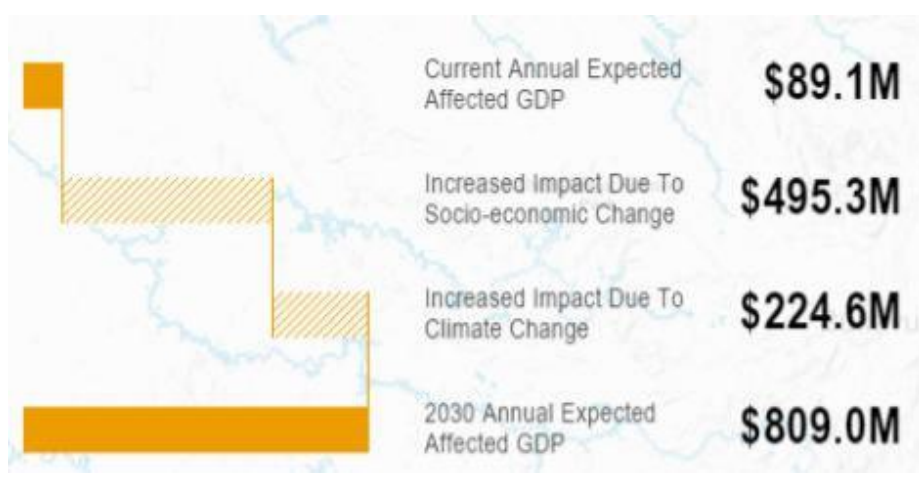

Fig. 22. Affected GDP in Rwanda for 2030 based on Scenario A.

In Figure 22, the current annual expected affected GDP in Rwanda is $\$ 89.1$ million accounting for its existing country-wide average 10-year flood protection. By 2030 assuming there is no additional flood protection introduced, roughly $68.8 \%$ of the expected increase in annual affected GDP in Rwanda could be driven by socio-economic change. By 2030 assuming there is no additional flood protection introduced, 31.2\% roughly of the expected increase in annual expected affected GDP in Rwanda could be driven by climate change. By 2030 assuming there is no additional flood protection introduced, annual affected GDP could reach $\$ 809.0$ million in Rwanda. In Figure 23, the affected GDP in Rwanda for 2030 based on Scenario B is given.

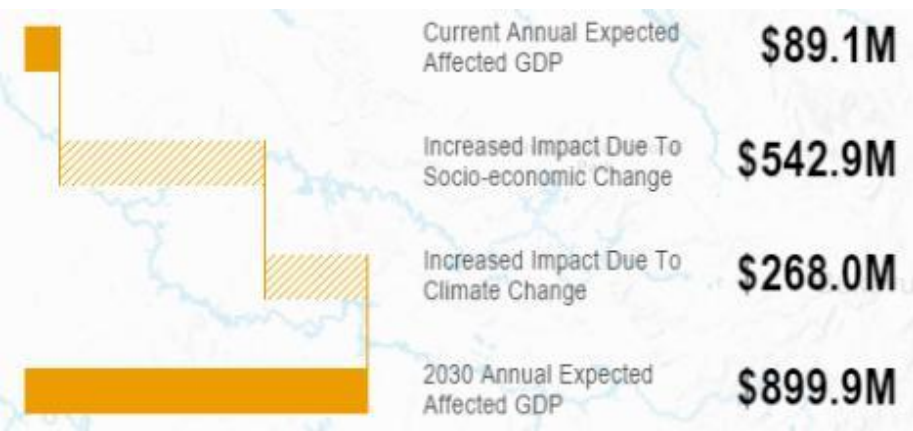

Fig. 23. Affected GDP in Rwanda for 2030 based on Scenario B.

In Figure 23, the current annual expected affected GDP in Rwanda is $\$ 89.1$ million accounting for its existing country-wide average based on a 10-year flood protection. By 2030 assuming there is no additional flood protection introduced, roughly $67.0 \%$ of the expected increase in annual affected GDP in Rwanda could be driven by socio-economic change. By 2030 assuming there is no additional flood protection introduced, $33.0 \%$ roughly of the expected increase in annual expected affected GDP in Rwanda could be driven by climate change. By 2030 assuming there is no 
additional flood protection introduced, annual affected GDP could reach $\$ 899.9$ million in Rwanda. In Figure 24, the affected GDP in Rwanda for 2030 based on Scenario C is given.

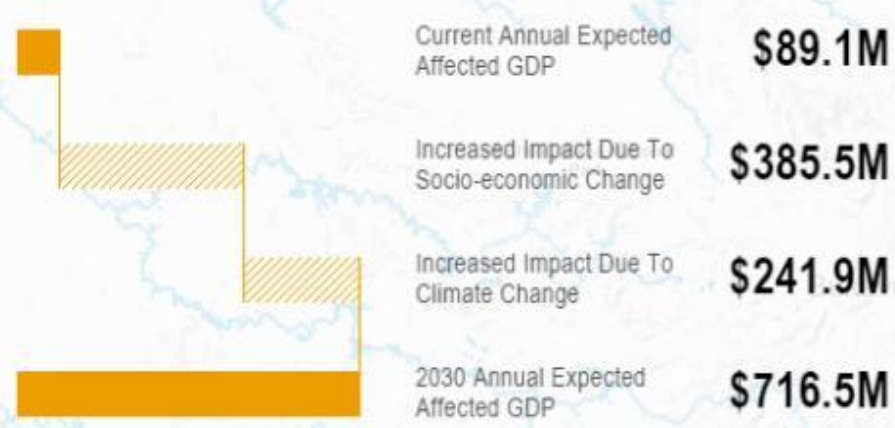

Fig. 24. Affected GDP in Rwanda for 2030 based on Scenario C.

In Figure 24, the current annual expected affected GDP in Rwanda is $\$ 89.1$ million accounting for its existing country-wide average based on a 10-year flood protection. By 2030 assuming there is no additional flood protection introduced, roughly $61.4 \%$ of the expected increase in annual affected GDP in Rwanda could be driven by socio-economic change. By 2030 assuming there is no additional flood protection introduced, $38.6 \%$ roughly of the expected increase in annual expected affected GDP in Rwanda could be driven by climate change. By 2030 assuming there is no additional flood protection introduced, annual affected GDP could reach $\$ 716.5$ million in Rwanda.

\subsubsection{Affected Population}

Affected population estimates the annualized number of people affected by inland flooding in any given area. The Global Flood Analyzer overlays a global inundation map on a global population map to estimate total population exposed to inland floods [19]. In Figure 25, the affected Population based on a ten (10) year flood protection level in Rwanda is given.
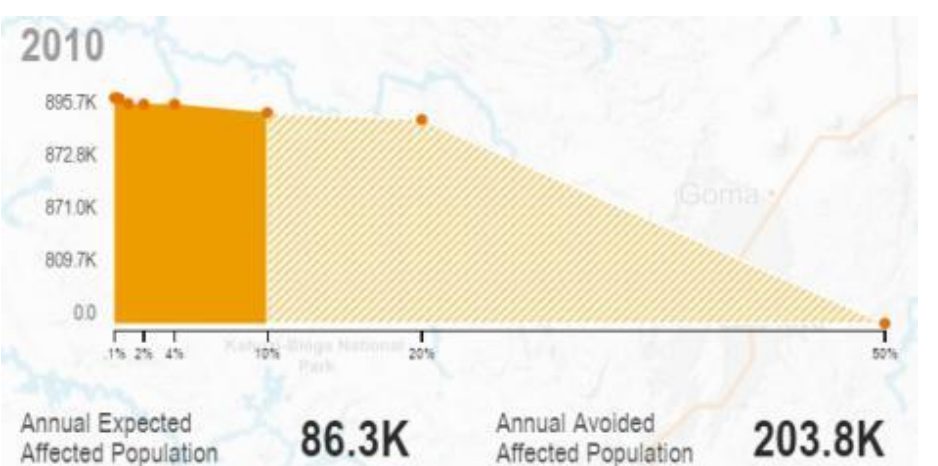

In Figure 25, a 1000-year flood has a $0.1 \%$ probability of occurring in any given year, and could cause roughly 895.7 thousand affected population in Rwanda, if there is no flood protection. A 250-year flood has a $0.4 \%$ probability of occurring in any given year, and could cause roughly 893.8 thousand affected population, if there is no flood protection. A 100-year flood has a $1 \%$ probability of occurring in any given year, and could cause roughly 872.8 thousand affected population, if there is no flood protection. A 50 -year flood has a $2 \%$ probability of occurring in any given year, and could cause roughly 871.3 thousand affected population, if there is no flood protection. A 25-year flood has a $4 \%$ probability of occurring in any given year, and could cause roughly 871.0 thousand affected population, if there is no flood protection. A 10-year flood has a 10\% probability of occurring in any given year, and could cause roughly 837.2 thousand affected population, if there is no flood protection. A 5-year flood has a $20 \%$ probability of occurring in any given year, and could cause roughly 809.7 thousand affected population, if there is no flood protection. A 2 -year flood has a $50 \%$ probability of occurring in any given year, and could cause roughly 0.0 affected population in Rwanda, if there is no flood protection. In Figure 26, the affected population in Rwanda for 2030 based on Scenario A is given.

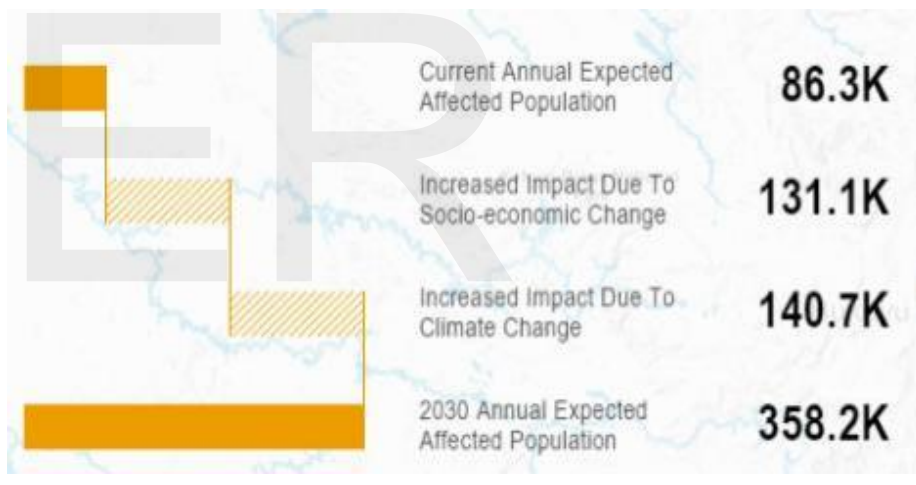

Fig. 26. Affected Population for 2030 based on Scenario A.

In Figure 26, the current annual expected affected population in Rwanda is 86.3 thousand accounting for its existing country-wide average based on a 10-year flood protection. By 2030 assuming there is no additional flood protection introduced, roughly $48.2 \%$ of the expected increase in annual affected population in Rwanda could be driven by socio-economic change. By 2030 assuming there is no additional flood protection introduced, $51.8 \%$ roughly of the expected increase in annual expected affected population in Rwanda could be driven by climate change. By 2030 assuming there is no additional flood protection introduced, annual affected GDP could reach 358.2 thousand in Rwanda. In Figure 27, the affected population in Rwanda for 2030 based on Scenario B is given.

Fig. 25. Affected Population based on a 10 year flood protection level. 


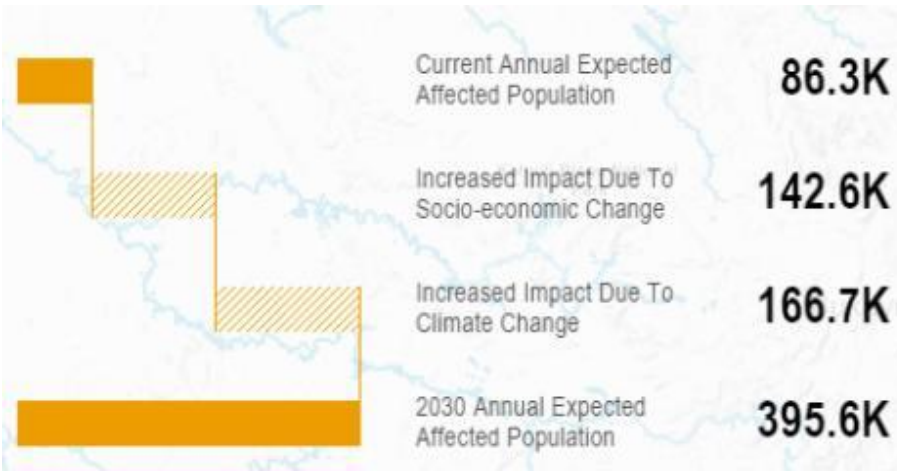

Fig. 27. Affected Population for 2030 based on Scenario B.

In Figure 27, the current annual expected affected population in Rwanda is 86.3 thousand accounting for its existing country-wide average based on a 10-year flood protection. By 2030 assuming there is no additional flood protection introduced, roughly $46.1 \%$ of the expected increase in annual affected population in Rwanda could be driven by socio-economic change. By 2030 assuming there is no additional flood protection introduced, 53.9\% roughly of the expected increase in annual expected affected population in Rwanda could be driven by climate change. By 2030 assuming there is no additional flood protection introduced, annual affected GDP could reach 395.6 thousand in Rwanda. In Figure 28, the affected population in Rwanda for 2030 based on Scenario C is given.

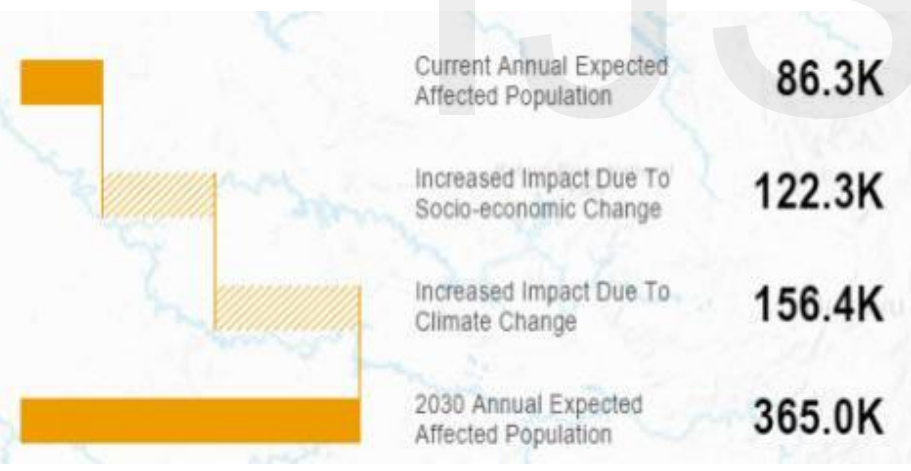

Fig. 28. Affected Population for 2030 based on Scenario C.

In Figure 28, the current annual expected affected population in Rwanda is 86.3 thousand accounting for its existing country-wide average based on a 10-year flood protection. By 2030 assuming there is no additional flood protection introduced, roughly $43.9 \%$ of the expected increase in annual affected population in Rwanda could be driven by socio-economic change. By 2030 assuming there is no additional flood protection introduced, 56.1\% roughly of the expected increase in annual expected affected population in Rwanda could be driven by climate change. By 2030 assuming there is no additional flood protection introduced, annual affected GDP could reach 365.0 thousand in Rwanda.

\subsection{Drought Severity Assessment in Rwanda}

In Figure 29, the drought severity map of Rwanda is given. Using AQUEDUCT Water Risk Atlas for drought severity analysis, Rwanda has a low to medium (10-27\% probability) drought severity. This is the average of the length times the dryness of droughts from 1901 to 2008 [29].

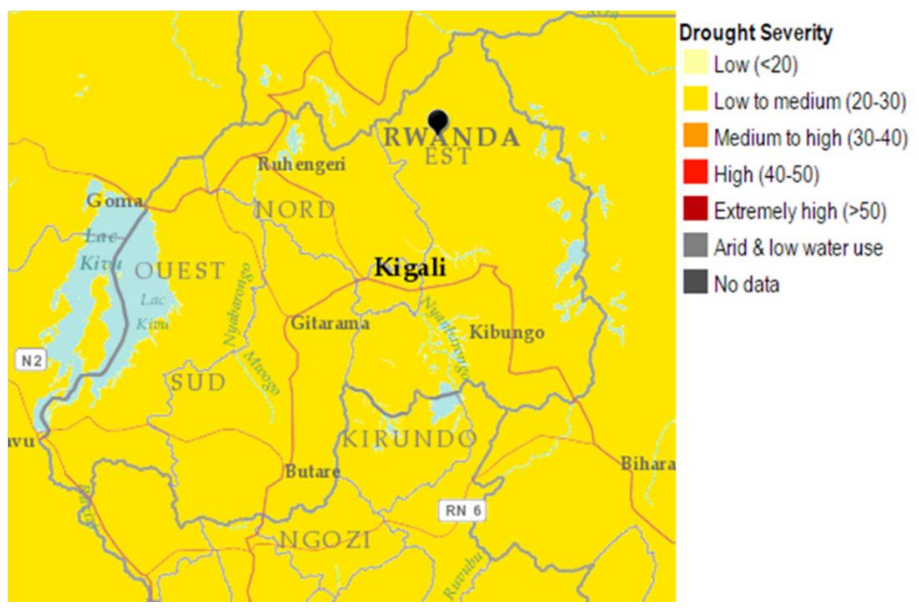

Fig. 29. Drought Severity Map of Rwanda.

\section{CONCLUSION}

Flood and drought events cannot be totally eradicated but with mitigation approach and preparedness before its occurrence, social and economic losses can be minimized. In this paper, situational analysis of flood and drought in Rwanda were assessed using AQUEDUCT Global Flood Analyzer based on the population, Gross Domestic Product (GDP) and urban damage for both current and the future (2030). In order to estimate future changes, three scenarios from: Representative Concentration Pathways (RCP) and Shared Socio-economic Pathways (SSP) from the Intergovernmental Panel on Climate Change $5^{\text {th }}$ Assessment Report which represents climate change and socioeconomic change scenarios respectively were employed. Data from 19812010 were used to determine the average monthly precipitation for current years and IPCC scenario A2 was used to generate datasets that predict the average monthly precipitation from 20112100 using Meteonorm 7 software. A 10-year flood protection level was used to ascertain the rate of urban damage, how it affects Gross Domestic Product (GDP) and the population at risk. The study revealed that Rwanda has more than $20 \%$ probability of inland flooding in any given year; a 10-year flood has a $10 \%$ probability of occurring in any given year, and could cause roughly \$6.1 million urban damage in Rwanda, \$865.6 million affected GDP, and 837.2 thousand affected population, if there is no flood protection. 


\section{ACKNOWLEDGEMENT}

Patrick Rufangura acknowledges the support of the Government of Rwanda for financial support towards his graduate studies through the Rwanda Education Board; sponsorship number 911/12.00/SR/2013.

\section{REFERENCES}

[1] Earthzine.org, (2013). IEEE Publication Fostering Earth Observation and Global Awareness. Retrived from: <http://www.earthzine.org/. Accessed on: 29/11/2013>

[2] Nicholas R. Bond, P. S. Lake and Angela H. Arthington. Impacts of drought on freshwater ecosystems: Australian perspective. Hydrobiologia (2008) 600:3-16.

[3] Agence France-Presse (2007). Flooding caused 210 deaths in West Africa, said UN. Published on $17^{\text {th }}$ October, 2007. Accessed on: $24^{\text {th }}$ October, 2014. Available at: <http://m.reliefweb.int/report/246180>.

[4] Rwanda Environment Management Authority (REMA), (2013). Chap9: climate change and natural disasters. Retrived from: www.rema.gov.rw/soe/chap9.pdf >. Accessed on: 27/12/2013.

[5] Rwanda meteorology office service, (2013). Retrived from: $<$ http:/www.meteorwanda.gov.rw/index.php?id=37/. Accessed on: 9/12/2013>.

[6] Twagiramungu F., (2006). Environmental profile for Rwanda. Europian Comission, Rwanda.

[7] UNDP in Rwanda, About in Rwanda.UNDP in Rwanda, (2013). Retrived <http://www.undp.org/content/rwanda/en/home/countryinfo/s. Accessed on: 26/12/2013

[8] Rwanda Environment Management Authority (REMA). Chap3: Land use and agriculture. Retrived from: www.rema.gov.rw/soe/chap3.pdf. Accessed on: 27/12/2013

[9] Rwanda New times (2013). Retrived from: $<$ <ttp://www.newtimes.co.rw/news/index.php?i=15268\&a=6387/>. Accessed on: 27/12/2013.

[10] EM-DAT: The OFDA/CRED International Disaster Database, www.emdat.be- Université catholique de Louvain - Brussels Belgium.

[11] Republic of Rwanda, Ministry of Disaster Management a Refugee affairs (MIDMAR), (2012). Disaster management plan.

[12] Hategekimana, S., \& Twarabamenya, E. (2007, September). The impact of wetlands degradation on water resources management in Rwanda: the case of Rugezi Marsh. In Proceedings of the 5th International Symposium on Hydrology.

[13] Munyaneza O.,Ndayisaba C., Wali U.G., Mulungu, D.M.M, and Dulos S.O., (2012). Integrated flood and drought Management for sustainable Development in Kagera River.

[14] Times, T. (2013). The New Times, Rwanda. Retrived from: <http://www.newtimes.co.rw/news/index.php?a=54593\&i=15018/. Accessed on: 29/11/2013.

[15] Asumadu-Sarkodie, S., Owusu, P. A., \& Jayaweera, H. M (2015). Flood risk management in Ghana: A case study in Accra. Advances in Applied Science Research, 6 (4). pp. 196-201.

[16] Republic of Rwanda, District of Bugesera (2013). Retrived from: $<\mathrm{http}$ ://www.bugesera.gov.rw/index.php?id=495/>. Accessed on: 29/12/2013.

[17] Pachauri, R. K., Allen, M. R., Barros, V. R., Broome, J., Cramer, W., Christ, R., \& Dasgupta, P. (Eds.). (2014). Climate Change 2014:
Synthesis Report. Contribution of Working Groups I, II and III to the Fifth Assessment Report of the Intergovernmental Panel on Climate Change. Intergovernmental Panel on Climate Change.

[18] Raleigh, C., Choi, H. J., \& Kniveton, D. (2015). The devil is in the details: An investigation of the relationships between conflict, food price and climate across Africa. Global Environmental Change, 32, 187199.

[19] Floods.wri.org, (2015). Aqueduct Global Flood Analyzer. Retrieved 24 May 2015, from <http:/floods.wri.org/\#/country/187/Rwanda>.

[20] IPCC, (2012): Workshop Report of the Intergovernmental Panel on Climate Change Workshop on Socio-Economic Scenarios. [Edenhofer, O., R. Pichs-Madruga, Y. Sokona, V. Barros, C.B. Field, T. Zwickel, S. Schloemer, K. Ebi, M. Mastrandrea, K. Mach, C. von Stechow (eds.)]. IPCC Working Group III Technical Support Unit, Potsdam Institute for Climate Impact Research, Potsdam Germany, pp. 51.

[21] Gassert, F., M. Luck, M. Landis, P. Reig, and T. Shiao. (2014). "Aqueduct Global Maps 2.1: Constructing Decision-Relevant Global Water Risk Indicators." Working Paper. (Washington, DC: World Resources Institute, 2014). http://www.wri.org/publication/aqueductglobalmaps-21-indicators.

[22] Brakenridge, G. R. (2010). Global active archive of large flood events. Dartmouth Flood Observatory, University of Colorado. Available online: <http://floodobservatory.colorado. edu/index. html > (accessed on 24 May 2015).

[23] Sheffield, J., \& Wood, E. F. (2008). Projected changes in drought occurrence under future global warming from multi-model, multiscenario, IPCC AR4 simulations. Climate dynamics, 31(1), 79-105.

[24] Wri.org, (2015). Aqueduct Water Risk. Retrieved 24 May 2015, from $<$ http://www.wri.org/applications/maps/aqueductatlas/\#x=30.10\&y=1 $.93 \& \mathrm{~s}=\mathrm{ut} ! 20$ ! 28 ! $\mathrm{c} \& \mathrm{t}=$ waterrisk $\& \mathrm{w}=\mathrm{def} \& \mathrm{~g}=0 \& \mathrm{i}=\mathrm{BWS}-16$ !WSV-4!SV2!HFO-4!DRO-4!STOR-8!GW-8!WRI-4!ECOS-2!MC-4!WCG-8!ECOV2 !\&tr=ind- 1 !prj-1\&l=8\&b=usa-topo\&m=single-WCG $>$.

[25] UNICEF, W. (2012). WHO Joint Monitoring Programme for Water Supply and Sanitation. Progress on Drinking Water and Sanitation: Special Focus on Sanitation.

[26] Smith School of Enterprise and Environment (SSEE), (2011). Rwanda's climate: observation projections Appendix E.

[27] Republic of Rwanda, (2011). Green Growth and Climate Resilience: National Strategy for Climate Change and Low Carbon Development.

[28] Wri.org, (2015). Aqueduct Water Risk. Retrieved 24 May 2015, from $<\mathrm{http}$ ://www.wri.org/applications/maps/aqueductatlas/\#x=30.10\&y=1 $.93 \& s=u t ! 20 ! 28 ! c \& t=w a t e r r i s k \& w=$ def $\& g=0 \& i=B W S-16 ! W S V-4 ! S V-$ 2!HFO-4!DRO-4!STOR-8!GW-8!WRI-4!ECOS-2!MC-4!WCG-8!ECOV2 ! $\mathrm{tr}=$ ind -1 ! prj- $1 \& \mathrm{l}=8 \& \mathrm{~b}=$ usa-topo $\& \mathrm{~m}=$ single-HFO $>$.

[29] Wri.org, (2015). Aqueduct Water Risk. Retrieved 24 May 2015, from http://www.wri.org/applications/maps/aqueductatlas/. 